\title{
VIETNAM'S TEXTILE AND GARMENT INDUSTRY: AN OVERVIEW
}

\author{
Tran Thi Bich Nhung*1, Tran Thi Phuong Thuy ${ }^{2}$ \\ ${ }^{1}$ Foreign Trade University Hochiminh city branch, 15 D5 Street 25 Ward Binh Thanh District, \\ HochiminhCity, 084, Vietnam, tranthibichnhung.cs2@ftu.edu.vn, (0938028655) \\ ${ }^{2}$ University Hochiminh city branch, 15 D5 Street 25 Ward Binh Thanh District, HochiminhCity, 084, \\ Vietnam tranthiphuongthuy.cs2@ftu.edu.vn, (0908934282)
}

\begin{abstract}
Vietnam's textile and garment industry has been developing strongly and plays an increasingly important role in economic growth of the country. This industry also has a great impact on Vietnam's socio-economic development. At the same time, the textile and garment industry employs more than 1.6 million people, accounting for more than $12 \%$ of the industrial workforce and nearly $5 \%$ of the country's total labor force. This article aims to provide an overview of the Vietnam's textile and garment industry and the vision of Vietnam's textile and garment industry to 2030. The results show that Vietnam's textile and garment industry has contributed great value to Vietnam's exports and GDP as well as solving employment. However, the Vietnam's textile and garment industry still has some limitations. First, the mode of production is mainly based on the CMT (the mode of production produces the lowest added value). Second, the incomes and capacities of the labors have not matched with the development of the industry. Third, the size of enterprises is small, so the competitiveness of Vietnam's textile and garment industry is limited in the international arena.
\end{abstract}

\section{Keywords}

Textile industry, garment industry, GDP, foreign market.

\section{JEL Classification}

L6, L7, M2

DOI: https://doi.org/10.14311/bit.2018.02.05

Editorial information: journal Business \& IT, ISSN 2570-7434, CreativeCommons license (c) (i) published by CTU in Prague, 2018, http://bit.fsv.cvut.cz/ 


\section{Introduction}

According to Nguyet A. Vu (2014), the textile and garment industry is one of the key industries in the consumer goods industry, contributing to meet the demand of consumers as well as the other industries and solve employment for labors, increase social welfare. Vietnam textile and garment industry consists of two major parts: textile and garment. The textile sector includes fiber spinning, shuttle weaving, dyeing and finishing. The garment sector uses the main material as fabric and some other accessories such as thread, lace, button, etc., through designing, cutting and using the sewing machine to make the final garment. The textile and garment enterprises are businesses operating in the field from spinning, weaving, dyeing, and finishing fabrics to materials such as thread, laces, buttons, cutter, auxiliary equipment and final products.

According to Le Hong Thuan (2017), Vietnam's textile and garment industry has been developing strongly and plays an increasingly important role in the growth of the national economy. Therefore, the business efficiency as well as the existence and development of textile and garment enterprises have great impact on the social-economic development of Vietnam. In the last five years, the textile and garment industry has a high export turnover with an average growth rate of about $15 \%$ over the years, contributing about $15 \%$ of the total export turnover of Vietnam. Vietnam is the fourth largest textile and garment exporter in the world, following China, India and Bangladesh, especially during the economic crisis from 2008 to 2014. In addition, the textile and garment industry employs over 1.6 million people, accounting for more than $12 \%$ of the industrial workforce and nearly $5 \%$ of the country's total labor force, contributing to improving living standards and social stability. In addition, export of textile and garment helps to bring in foreign earnings to invest in machinery and modernization of production. According to many experts, besides these great achievements, the textile and garment industry still has certain limitations, such as the stages in the production process are uneven so the production is mainly based on garment processing, export products are not diversified and the supporting industries are not adequately developed. Increasingly, the size of enterprises is mainly small enterprises, management skills are limited, labor productivity is not high and marketing capacity is not suitable with production capacity, businesses have almost no long-term development strategy. Therefore, Vietnamese enterprises cannot enjoy huge profits from the textile and garment industry.

\section{Methodology}

To perform this study, the authors used desk research methods with secondary data collected from Vietnamese government agencies such as General Statistics Office of Vietnam, General Department of Vietnam Customs, Ministry of Industry and Trade and other reliable sources. Based on that, the authors synthesized, systematized, analyzed, and evaluated data to obtain research results.

\section{Results}

\section{Current situation of Vietnam textile and garment industry}

\subsection{Industrial production and export of Vietnam textile and garment industry}

The index of industrial production and exports of Vietnam textile and garment industry over the years is shown in Table 1. 
Table 1. Index of industrial production and exports of Vietnam textile and garment (2012 to 2017).

(Unit: US\$ mil.,\%)

\begin{tabular}{|l|l|l|l|l|l|l|}
\hline \multicolumn{1}{|c|}{ Indicators } & \multicolumn{1}{c|}{$\mathbf{2 0 1 2}$} & \multicolumn{1}{c|}{$\mathbf{2 0 1 3}$} & \multicolumn{1}{c|}{$\mathbf{2 0 1 4}$} & \multicolumn{1}{c|}{$\mathbf{2 0 1 5}$} & $\mathbf{2 0 1 6}$ & $\mathbf{2 0 1 7}$ \\
\hline Textile & $104.2 \%$ & $121.2 \%$ & $119.7 \%$ & $114.0 \%$ & $116.9 \%$ & $110.2 \%$ \\
\hline Garment & $107.5 \%$ & $110.9 \%$ & $112.2 \%$ & $104.6 \%$ & $107.5 \%$ & $106.1 \%$ \\
\hline $\begin{array}{l}\text { Textile and garment } \\
\text { exports }\end{array}$ & 15,090 & 17,933 & 20,911 & 22,802 & 23,835 & 26,120 \\
\hline $\begin{array}{l}\text { Textile and garment } \\
\text { exports' growth }\end{array}$ & $7.5 \%$ & $18.8 \%$ & $16.6 \%$ & $9.0 \%$ & $4.5 \%$ & $9.6 \%$ \\
\hline $\begin{array}{l}\text { Total exports of } \\
\text { Vietnam }\end{array}$ & 114,530 & 132,033 & 150,217 & 162,017 & 176,580 & 215,120 \\
\hline $\begin{array}{l}\text { The percentage of } \\
\text { textile and garment } \\
\text { exports versus total } \\
\text { exports }\end{array}$ & $13.2 \%$ & $13.6 \%$ & $13.9 \%$ & $14.1 \%$ & $13.5 \%$ & $12.1 \%$ \\
\hline
\end{tabular}

Source: Compiled from data of General Statistics Office of Vietnam, General Department of Vietnam Customs

Industrial production index shows that the industrial production of textile and garment industry has increased over the years. Specifically, the average annual growth rate of the textile industry is about $14.4 \%$ and the garment industry is about $8.1 \%$.

\subsection{Main markets and products}

The products of Vietnam's textile and garment industry are sold in both domestic and foreign markets. In the domestic market, they are sold in markets, retail stores, supermarkets, trade centers and accounts for about $14 \%$. The products of Vietnam's textile and garment industry are exported to more than 180 countries and territories worldwide (Le Hong Thuan, 2017). In particular, the main markets are the United States, the EU, Japan, Korea, and some other markets such as ASEAN, Canada, China, and Taiwan.

Export turnover and proportion of export turnover in some major markets of Vietnam textile and garment industry in the period from 2012 to 2017 are shown in the Table 2. 
Table 2. Main export market of Vietnam's textile and garment industry (2012 to 2017).

(Unit: US\$ mil.,\%)

\begin{tabular}{|c|r|r|r|r|r|r|}
\hline Market/year & \multicolumn{1}{|c|}{$\mathbf{2 0 1 2}$} & \multicolumn{1}{|c|}{$\mathbf{2 0 1 3}$} & \multicolumn{1}{|c|}{$\mathbf{2 0 1 4}$} & \multicolumn{1}{c|}{$\mathbf{2 0 1 5}$} & \multicolumn{1}{c|}{$\mathbf{2 0 1 6}$} & \multicolumn{1}{c|}{$\mathbf{2 0 1 7}$} \\
\hline \multirow{2}{*}{ US } & 7,457 & 8,600 & 9,807 & 10,947 & 11,442 & 12,275 \\
\cline { 2 - 7 } & $49.4 \%$ & $48.0 \%$ & $46.9 \%$ & $48.0 \%$ & $48.0 \%$ & $47.0 \%$ \\
\hline \multirow{2}{*}{ EU } & 2,456 & 2,723 & 3,333 & 3,470 & 3,562 & 3,785 \\
\cline { 2 - 7 } & $16.3 \%$ & $15.2 \%$ & $15.9 \%$ & $15.2 \%$ & $14.9 \%$ & $14.5 \%$ \\
\cline { 2 - 7 } & 1,975 & 2,380 & 2,620 & 2,785 & 2,899 & 3,110 \\
\hline \multirow{2}{*}{ South Korea } & $13.1 \%$ & $13.3 \%$ & $12.5 \%$ & $12.2 \%$ & $12.2 \%$ & $11.9 \%$ \\
\cline { 2 - 7 } & 1,069 & 1,639 & 2,089 & 2,128 & 2,283 & 2,642 \\
\hline \multirow{2}{*}{ Others } & $2,1 \%$ & $9.1 \%$ & $10.0 \%$ & $9.3 \%$ & $9.6 \%$ & $10.1 \%$ \\
\cline { 2 - 7 } & $14.1 \%$ & $14.4 \%$ & $14.6 \%$ & $15.2 \%$ & $15.3 \%$ & $16.5 \%$ \\
\hline \multirow{2}{*}{ Total } & 15,090 & 17,933 & 20,911 & 22,802 & 23,835 & 26,120 \\
\hline
\end{tabular}

Source: Compiled from General Department of Vietnam Customs

Table 2 shows that Vietnam's textile and garment are mostly exported to the US market, followed by the European Union and Japan. Recently, Vietnam's textile and garment industry has expanded its export to South Korea. Specifically, in 2012, the proportion of exports to South Korean market was only $7.1 \%$. By 2016, the proportion of exports to this market was $9.6 \%$. These market are notorious for being extremely strict in terms of product quality, price and apperance. In addition, these markets are also very demanding in product control and the standard for the product. Typically, besides the requirement to meet the standards of textile and garment of Vietnam such as: TCVN 6054:1995 on common clothing; TCVN 4737:1989 on textiles and garments - list of quality criteria; TCVN 2109:1977 on garments - sampling methods; QCVN 13:2008/BTNMT on textile and garment industry sewage water ..., exports of Vietnam textile and garment to countries should meet the requirements of each importing country such as: ISO 9001; SA-8000 standards of corporate social responsibility, compliance with customs regulations on origin for garment and textile products (19 C.F.R Part 102), labeling and garment manual (16 C.F.R Part 423).

In terms of product categories, Vietnam textile and garment products mainly consist of jackets, t-shirts, pants and shirts, skirts, children's clothing and other products such as: vest clothes, sweaters, swimwear towel. In particular, in 2013, export value of jackets reached 3.88 billion USD; up 19.6\% over the same period and accounted for $21.6 \%$ of total garment export value. T-shirts and trousers witnessed impressive growth rate of $23.7 \%$ and $25.8 \%$ respectively over the same period with the export value of US\$ 3.76 billion and US\$ 3.01 billion, accounting for about $20.9 \%$ and $16.8 \%$ of the total value of garment export. Shirts has export value of about US\$ 1 billion, growing by $14.6 \%$ and accounting for $5.7 \%$ of total textile and garment export value. Other products such as skirts accounting for $5.5 \%$, children's clothing accounting for $5.0 \%$, and the remaining products accounting for $24.6 \%$ (Bui Van Tot, 2014). 


\subsection{Main modes of production}

The main modes of production in Vietnam textile and garment industry is shown in Figure 1.

Figure 1. Main modes of production of Vietnam's textile and garment industry.

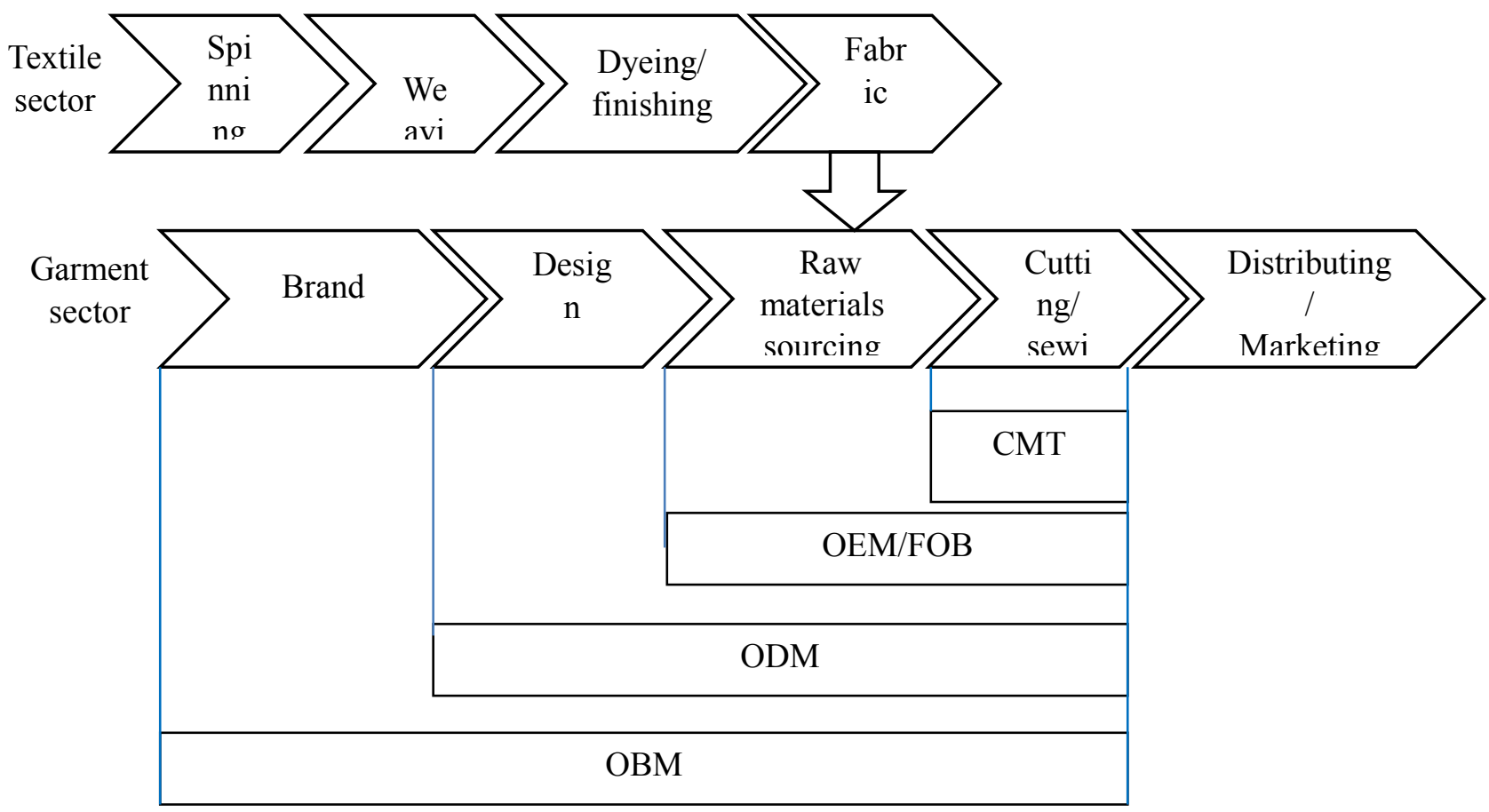

Source: Bui Van Tot, 2014

CMT (Cut - Make - Trim): this is the easiest export method of textile and garment industry and brings the lowest added value. When cooperation under this method, purchasers offer entire input to outsourcing businesses for production including raw materials, transportation, design and specific requirements; manufacturers only carry out stages of cutting, sewing and finishing products. Businesses following export method of CMT only need the basic understanding of design patterns and the ability to produce finished product.

OEM/FOB (Original Equipment Manufacturing): FOB export method creates higher value compared to CMT; which is the production method of "buying raw materials, selling products". Businesses are actively involved in the production process on $\mathrm{FOB}$, from acquisition of raw materials to production of final products. Unlike CMT, exporters using FOB actively buy necessary material inputs instead of being supplied directly from their buyers. The activities under the FOB have significantly changed based on forms of the actual contractual relations between suppliers and foreign buyers and are divided into 2 types (FOB level I and FOB level II). Regarding FOB level I, businesses will purchase inputs from a group of suppliers specified by buyers. This method requires garment enterprises to bear the financial responsibility for the procurement and transportation of materials. Regarding FOB level II, businesses will receive product designs from foreign buyers and take full responsibility for sources of raw materials, production, and transportation of raw materials and finished goods to ports specified by buyers. The bottom line is that businesses must find the material suppliers with capability of providing special materials, and having confidence in the quality and delivery time. Risks from this method are higher but manufacturing companies also receive higher added value.

ODM (Original Design Manufacturing): this method of production for export includes the design and production process of purchasing fabric and materials, cutting, sewing, finishing, packaging and shipping products. The ability to design reflects the higher level of knowledge of the providers and 
therefore will bring higher added value for products. ODM businesses create designs, finish products and sell them to buyers, which are most of the owners of major brands in the world.

OBM (Original Brand Manufacturing): this method of production is improved based on method of OEM, but the manufacturers are responsible for their own designs and sign domestic and foreign goods' supply contracts for their own brands. Manufacturers in developing economies following OBM method mainly distribute products in their domestic market and markets of neighboring countries.

Although Vietnam's textile and garment industry has a high proportion of export turnover and high growth rate, it is mainly manufactured under the CMT method (the mode of production produces the lowest added value). This method accounted for $76 \%$ of total export value. About $21 \%$ of export value is produced by FOB mode and only $3 \%$ of production value is by other mode of production. Vietnamese enterprises exporting by FOB method are mainly FOB level I (buying raw materials according to customers' specifications). Therefore, the value added of the industry is still low (Nguyet A. Vu, 2014). The main cause of the problem is that Vietnamese textile and garment enterprises have not been able to actively source raw materials, weak management capacity and limited ability to raise capital. Especially, Vietnam's garment industry is weak in product design because of the lack of good designers, lack of information about customer demand as well as far away from the end-user market. In addition, the uneven development of the supporting industries also greatly influenced the development of the textile and garment industry. According to statistics of Vietnam Textile and Garment Association, more than $70 \%$ of textile and garment materials in Vietnam are still imported, therefore, this industry are much dependent on foreign markets.

\subsection{Labor in textile and garment industry}

Labor is one of the main factors of production and business in the textile and garment industry and is reflected in both the quantity and quality of labor. The textile and garment sector is characterized by labor intensive, manual processes. Therefore, the training of human resources is decisive for the sustainable development of the textile and garment industry in Vietnam. According to Le Hong Thuan (2017), the number of labors in the textile and garment industry is about 1.6 million people, accounting for more than $12 \%$ of the labor force in the industrial sector and nearly $5 \%$ of the total labor force in Vietnam. However, incomes of laborers in the textile and garment sector are not high (about 5.6 million VND/person/month, the income in the garment sector is about 5 million $\mathrm{VND}$ /person/month), lower than the average level of economic sector (about 6.3 million $\mathrm{VND}$ /person/month). In terms of productivity management, labor quality in textile and garment enterprises has received much attention, investment and improvement in recent years, but labor productivity is still lower than other countries in the region. Typically, the average labor productivity in the industry is one-third in comparison with Hong Kong, one-fourth in comparison with China, equals one-eighth in comparison with South Korea, and $90 \%$ in comparison with China in term of textile industry and $85 \%$ in comparison with Thailand. This greatly affects the cost, reducing the competitiveness of the product. At the same time, it causes direct difficulties for enterprises as the pressure on labor costs increases while labor productivity does not accordingly increase.

\subsection{Number and size of enterprises}

According to statistics by Bui Van Tot (2014), there are about 6,000 companies operating in the textile and garment sector in Vietnam, of which small and medium enterprises account for a large proportion. In terms of ownership, about $84 \%$ of textile and garment enterprises are private; $15 \%$ are foreign invested enterprises and about $1 \%$ is SOEs. By sector, about $70 \%$ of enterprises are in of the garment sector, $17 \%$ of enterprises are in the textile/knit sector, $6 \%$ of enterprises are in the yarn sector, $4 \%$ of enterprises are in the dyeing sector and $3 \%$ of enterprises are in the supporting industries. 
In terms of geography, enterprises in the north occupied about $30 \%$, enterprises in the central and highlands occupy $8 \%$, enterprises in the south occupies about $62 \%$.

\subsection{Marketing activities}

For garment export, distribution activities of Vietnamese garment enterprises are still underdeveloped and are heavily dependent on foreign traders. Vietnamese garment enterprises are still dependent on regional suppliers (in Hong Kong, Taiwan, Korea) to have outsourcing contracts. Very few garment enterprises have contracts directly from retailers to provide their products. A number of garment enterprises are still relying on representative offices in Vietnam of famous brands to provide products. For example, some local manufacturers for Columbia, Decathlon ... export directly to overseas firms through their representative offices in Vietnam. In other words, Vietnamese garment enterprises still lack the connection with end-users. They just implement subcontracts for regional producers. Therefore, Vietnamese garment enterprises cannot obtain huge profits as well as master the world fashion trend.

As for garments consumed domestically, distribution activities are being carried out by some Vietnamese brands which are familiar with consumers such as Format, NEM, Seven AM, Eva de Eva, Chic-land, Ivy Moda, Elise, Ninomax, Canifa, Aristino ... However, in comparison with world famous fashion brands planning to penetrate Vietnamese market in the future, Vietnamese enterprises still have some weaknesses in term of distribution and marketing activities.

As a result, distribution and marketing activities are one of shortages of Vietnam's textile and garment industry. Vietnamese enterprises mainly carry out processing contracts (CMT and FOB level I), therefore, there are few products of Vietnamese enterprises with their own brands to reach retailers across the globe. When Vietnam has still not got upstream links to be active in production activities with its own designs and brands, Vietnam's textile and garment industry is still unlikely to play an important role in the global textile and garment value chain.

\section{Development plan of Vietnam's textile and garment industry to $\mathbf{2 0 3 0}$}

According to Decision No.3218/QD-BCT approving the development plan of Vietnam textile and garment industry up to 2020 with a vision to 2030 , the Ministry of Industry and Trade has proposed some orientations and objectives for the development of Vietnam textile and garment as follows:

\subsection{Viewpoints on the development of Vietnam textile and garment industry}

- To develop the textile and garment industry in the direction of modernity, efficiency and sustainability, shifting the production from mere processing to the active purchase of raw materials and semi-finished products, ensuring the raising of quality and diversification of exports.

- Taking the export as a basis for the development of the sector and at the same time to meet the needs of domestic market. To concentrate on strongly developing supporting industries products, producing raw materials and auxiliary materials and enhancing added value of products in the industry.

- To develop the textile and garment industry in association with environmental protection and the trend of agricultural and rural labor movement. To develop concentrated textile-fiber clusters to facilitate environmental treatment. Transfer of labor-intensive textile and garment enterprises to rural areas, while developing the textile and garment market in big cities and cities.

- To develop human resources in both quantity and quality for the sustainable development of the textile and garment industry, paying special attention to the training of managerial officials, technicians and skilled workers in order to create a good entrepreneurs and skilled workforces.

- Mobilize resources to invest in textile and garment development, calling on foreign investors to invest in areas where domestic firms are weak and inexperienced. 


\subsection{Development objectives}

\section{a. Overall objectives}

- To build the textile and garment industry to become one of the leading and export-oriented industries as well as have capable of meeting the domestic demand, creating more and more jobs for the society, enhancing competitiveness and firm integration into the regional and global economy.

- To ensure the sustainable and efficient development of the textile and garment industry on the basis of modern technologies, quality management systems, labor management and environmental management in compliance with international standards.

- Distribution of textiles and garments in appropriate areas: favorable sources of labor, traffic and port.

- $\quad$ By 2020, the textile and garment industry will build some famous brands.

\section{b. Detailed goals}

- In the period up to 2020: The growth rate of industrial production value will reach $12 \%$ to $13 \% / y e a r$, of which the textile industry will increase by $13 \%$ to $14 \%$ /year, the garment industry will increase from $12 \%$ to $13 \%$ /year. Export growth is $9 \%$ to $10 \%$ per year. Domestic market growth is $10 \%$ to $12 \%$ per year.

- The period from 2021 to 2030: The growth rate of industrial production value will reach $9 \%$ to $10 \%$ per year. In which the textile industry increased by $10 \%$ to $11 \%$ / year, the garment sector increased from $9 \%$ to $10 \% / y e a r$. Export growth is $6 \%$ to $7 \%$ per year. Domestic market growth is from $8 \%$ to $9 \%$ per year.

Textile and garment structure in the textile and garment sector will be as follows: by 2020, the share of the textile sector will increase to $47 \%$, the textile sector will shrink by $53 \%$, and by 2030 the textile sector will increase to $49 \%$. Garment sector will account for $51 \%$ of total textile and garment industry.

Table 3. Some development goals of the textile and garment industry to 2020 and 2030 .

\begin{tabular}{|l|c|c|c|}
\hline \multicolumn{1}{|c|}{ Indicators } & Unit & $\mathbf{2 0 2 0}$ & $\mathbf{2 0 3 0}$ \\
\hline 1. Exports & US\$ billions & $36-38$ & $64-67$ \\
\hline $\begin{array}{l}\text { Percentage of exports versus } \\
\text { total exports }\end{array}$ & $\%$ & $13-14$ & $9-10$ \\
\hline 2. Labors & 1,000 people & 3,300 & 4,400 \\
\hline 3. Main products & 1,000 tons & 15 & \\
\hline Cotton fiber & 1,000 tons & 700 & 30 \\
\hline Fibers, synthetic fibers & 1,000 tons & 1,300 & 2,200 \\
\hline Fibers of all types & Million m2 & 2,000 & 4,500 \\
\hline Fabric & Million product & 6,000 & 9,000 \\
\hline Sewing product & \multicolumn{2}{|c|}{$\%$} & $65 \%$ \\
\hline 4. Localization & & 600 \\
\hline
\end{tabular}

Source: The Ministry of Industry and Trade, 2014 


\subsection{Product development orientation and planning layout}

First, strengthen the garment export to take advantage of market opportunities: Diversify and improve the level of clothing, develop high value added items. Improve the capacity of enterprises in the shift of production and business methods from the beginning to the final stage (CMT) to other forms such as OEM, FOB, ODM, OBM. Improve labor productivity, improve capacity in business management, sample design, quality management, trade promotion. Moving garment production from big cities to localities with labor resources and convenient transportation.

Second, work out programs for production of fabrics for export, development of technical textiles and textile products for medical purposes. Develop knitwear and woven products which are able to link yarn and garment production to promote the advantages of trade agreements such as CPTPP and FTA. Development of technical textile products, textile products for medical purposes. Focus on key areas to increase product quality and customer trust, in which dyeing, finishing is the most important;

The investment projects to produce yarns, weaving, dyeing, should select appropriate technology in the direction of improving product quality and less polluting the environment. Planning for dyeing and dyeing factories, finishing in certain locations to facilitate the supply of water and wastewater treatment. To invest in modern textile and garment clusters in the direction of value chains: producing raw materials, auxiliary materials and sewing FOB, ODM products.

Third, the development of cotton fiber resources, fibers, artificial fibers and auxiliary materials. Develop a cotton development program, which focuses on the development of irrigated cotton growing areas to increase the yield and quality of cotton fiber in the country, provided to the textile industry. Select, invest additional artificial fiber factories, step by step to meet the needs of the textile industry in terms of type, quality, quantity, aiming to increase the localization rate.

\section{Conclusion and discussion}

The textile and garment industry is one of the key industries in Vietnam, contributing great value to Vietnam's exports and GDP as well as solving employment. However, the Vietnam's textile and garment industry still has some limitations. First, the mode of production is mainly based on the CMT (the mode of production produces the lowest added value). Second, the incomes of the labors have not matched with the development of the industry. Third, the size of enterprises is small, so the competitiveness of Vietnam's textile and garment industry is limited in the international arena.

\section{References}

[1] Ministry of Trade and Industry (2014), Decision approving the development plan of Vietnam textile and garment to 2020, vision to 2030.

[2] Le Hong Thuan (2017), Report on textile and garment industry, FPT Securities.

[3] Bui Van Tot (2014), Report on textile and garment industry, FPT securities.

[4] Nguyet A. Vu (2014), Report on textile and garment industry, ViettinbankSc.

[5] Website của General Statistics Office of Vietnam: https://www.gso.gov.vn

[6] Website of General Department of Vietnam Customs: https://www.customs.gov.vn 